Vietnam Journal of Earth Sciences, 38(2), 202-216, DOI: 10.15625/0866-7187/38/2/8602

Vietnam Academy of Science and Technology
Vietnam Journal of Earth Sciences
http://www.vjs.ac.vn/index.php/jse

\title{
Assessment of geomorphic processes and active tectonics in Con Voi mountain range area (Northern Vietnam) using the hypsometric curve analysis method
}

\author{
Ngo Van Liem*1, Nguyen Phuc Dat², Bui Tien Dieu,4, Vu Van Phai5, Phan Trong Trinh¹, \\ Hoang Quang Vinh', Tran Van Phong ${ }^{1}$ \\ ${ }^{1}$ Institute of Geological Sciences, Vietnam Academy Science and Technology \\ ${ }^{2}$ Vietnam Institute of Geosciences and Mineral Resources, Ministry of Natural Resources and Environment \\ ${ }^{3}$ Geographic Information System Group, Department of Business Administration and Computer Science, University \\ College of Southeast Norway \\ ${ }^{4}$ Faculty of Geomatics and Land Administration, Hanoi University of Mining and Geology \\ ${ }^{5}$ Faculty of Geography, VNU University of Sciences
}

Received 25 January 2016. Accepted 7 June 2016

\section{ABSTRACT}

The main objective of this study is to assess geomorphic processes and active tectonics in the Day Nui Con Voi (DNCV) area of Vietnam. For this purpose, a spatial database was collected and constructed, including DEM (Digital Elevation Model) and a geological map. The hypsometric curve (HC) analysis method and its statistical moments were adopted to use for the assessment. These methods have been widely used for the assessment of geomorphic processes and active tectonics in many areas in the world showing promising results. A total of 44 sub-basins of the Red River and the Chay river were analyzed. The result shows that 3 curve-types such as "straight- shape", "Sshape", and concave were found; with the concave curve being the dominant and widely distributed in the northeast side and in the south of the southwestern side of the study area. The hypsometric integral (HI) values are rather small with the largest value is 0.37 and the smallest one is 0.128 . Other statistical moments of the hypsometric curve, i.e. skew (SK), kurtosis (KUR), and the density function (density skew - DSK and density kurtosis-DKUR) show great values, which increased in the south direction of the area study. Accordingly, recent active tectonics (uplift-lower) in the study area is generally weak; however, they are also not completely homogeneous and can be distinguished by different levels. The southwestern side is being lifted higher than the northeastern side. The northern part is being lifted larger than the southern part. In the region, the uplift activities were increased gradually in the PlioceneQuaternary and could have stopped at certain time in the past. The current geomorphic processes are mainly headward erosion in the upstream.

Keywords: Geomorphic index; Hypsometric curve; Statistical moments; Active tectonics; Red River fault; Day Nui Con Voi.

(C)2016 Vietnam Academy of Science and Technology

\section{Introduction}

The Red River shear zone (RRSZ) extends

*Corresponding author, Email: liem.igsvn@gmail.com over a length of $1000 \mathrm{~km}$ from Tibet to the East Vietnam Sea. Along the shear zone, four narrow massifs of high-grade metamorphic complexes, the Day Nui Con Voi in Vietnam, 
N.V. Liem, et al./Vietnam Journal of Earth Sciences 38 (2016)

Ailao Shan, Diancang Shan and Xuelong Shan in Yunnan, China are considered as the "axes" of the RRSZ - important geological boundaries in Asia. The Day Nui Con Voi range is in the southeasternmost part of this shear zone (Figure 1). This area has been received attentions of many geoscientists and seen as a key to understand the geodynamics of the RRSZ (Leloup et al., 1995; 2001; Le et al., 2004). The achieved results have contributed to the explanation and clarification of many issues in geology, tectonics and geomorphology. However, some points are not consistent and disputed (e.g. Tran et al., 1999; 2002; Le, 2003; Le et al., 2001; Phan et al., 2004; Wang et al., 2000; Leloup et al., 2001. Studies of tectonics in this area have not paid much attention to the role and significance of geomorphology; especially, the lack of quantitative analyses of landscapes using various geomorphic indices.

Geomorphic indices have been found to be useful in identifying areas experiencing tectonic activity because they facilitate rapid evaluation of large areas (Strahler, 1952; Bull and McFadden, 1977; Keller and Pinter, 2002; Joshi et al., 2013). Furthermore, active faults and growing folds commonly have topography that is useful in identifying different geomorphic or structural segments along the fault and estimating the most active segments (Azor et al., 2002; Font et al., 2010; Joshi et al., 2013). Segments along a morphostructure may be outlined and identified to determine the relative intensity of tectonic activity along a fault by utilizing a detailed study of drainage anomalies coupled with geomorphic indices (Azor et al., 2002; Keller and Pinter, 2002; Joshi et al., 2013). Moreover, with the current development of GIS, the calculation of geomorphic indices has become easier (Troiani and Della Seta, 2008; Pérez-Peña et al., 2009; Joshi et al., 2013). So, the geomorphic indices have been widely used in geomorphology and active tectonics (e.g., see in the above references).

In Vietnam, despite some initial geomorphic indices also to be used quite successfully in several studies such as Nguyen et al.
1999; Phung, 2011; Phan, 2014; Nguyen, 2015. However, most of the calculations in these studies were manually carried out based on topographic maps and satellite images; so the results often depend on the ability to estimate, sight and experience of experts who conducted these studies. Therefore, the analysis and assessment of geomorphic indices have not been shown clearly roles, the significances, and its relationship to the geomorphological processes and active tectonics.

In this paper, we present quantitative analyses and assessments of the hypsometric curve (HC) and its statistical moments in relationship between geomorphic processes and active tectonics in the DNCV area. The HC index is one of the geomorphic indices that has been considered as a powerful tool for quantifying the topographic features and differentiate zones deformed by active tectonics (Keller and Pinter, 2002; Chel et al., 2003; Pérez-Peña et al., 2009; Pedrera et al., 2009; Mahmood and Gloaguen, 2012). However, in Vietnam, this is the first time the method is adopted for the assessment of the active tectonics in the Lo River fault zone and the Tam Dao area (Ngo et al., 2016), but statistical moments of the hypsometric curve has not been analyzed and assessed.

\section{Tectonic, geologic, and geomorphic settings}

The Day Nui Con Voi (DNCV) mountain is less than $10 \mathrm{~km}$ wide and more than $250 \mathrm{~km}$ long, extending from Lao Cai to Viet Tri, and appearing as an elongated NW-trending core of metamorphic rocks (Tran et al., 1998) (Figure 1). The altitude of the mountain is peaked at Nui Lai of $1450 \mathrm{~m}$, then descending to the northwest and southeast. This mountain is characterized by three main strips, with the NW-SE direction and separated by the parallel lines with the Red River. The topography in this area is asymmetry: slope of the northeastern side is smaller than the southwest side; on the northeastern side have some narrow strips extending along the main mountain; the southwest side is divided into individual peaks. The center strip of the DNCV is uplifted (500-1000 m) compared with the two sides $(<500 \mathrm{~m})$ (Le et al., 2004). 
Vietnam Journal of Earth Sciences, 38(2), 202-216

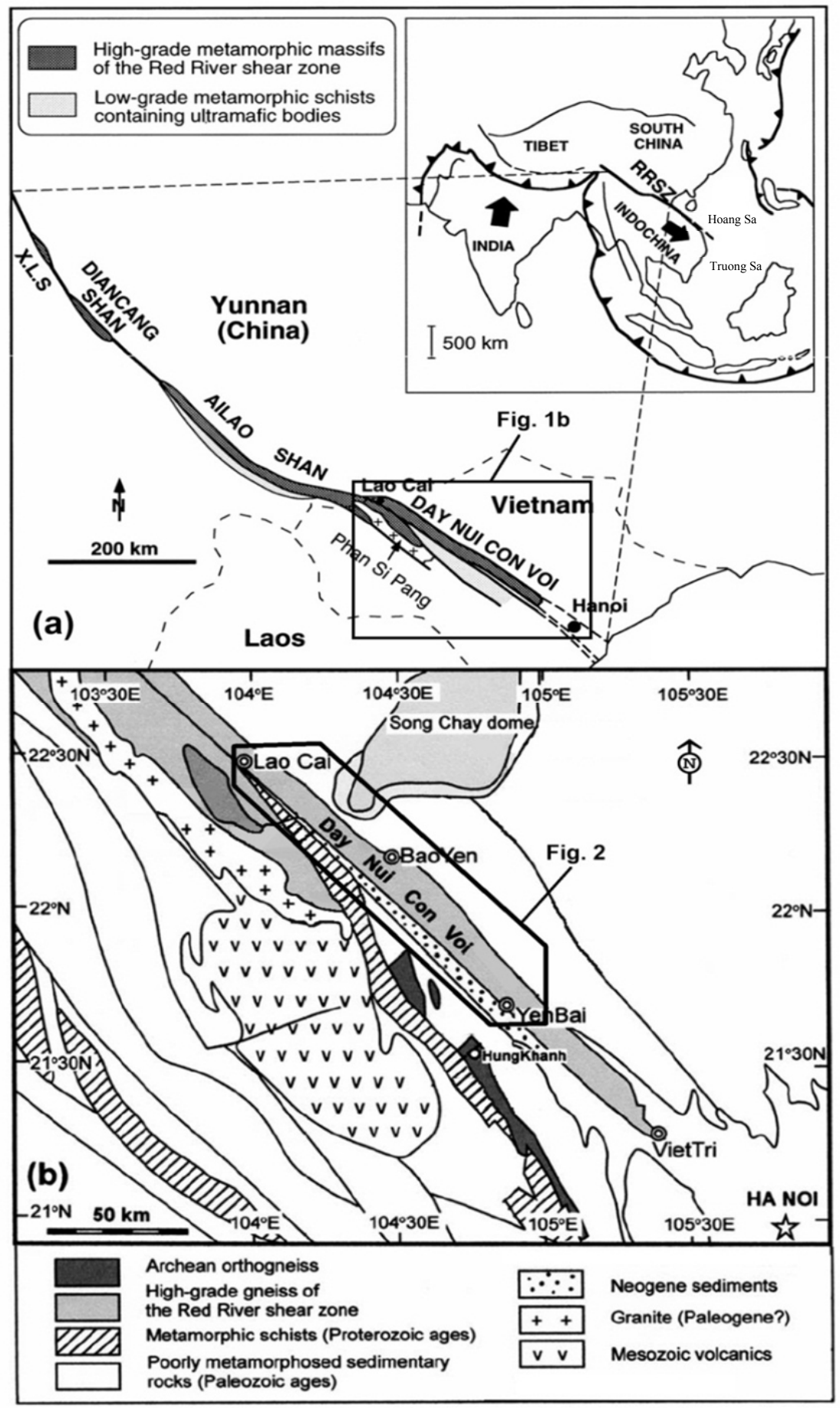

Figure 1. (a). The Red River shear zone in Asia, (b) geological sketch map around the Day Nui Con Voi (Modified after Tran et al., 1998; 2003) 
N.V. Liem, et al./Vietnam Journal of Earth Sciences 38 (2016)

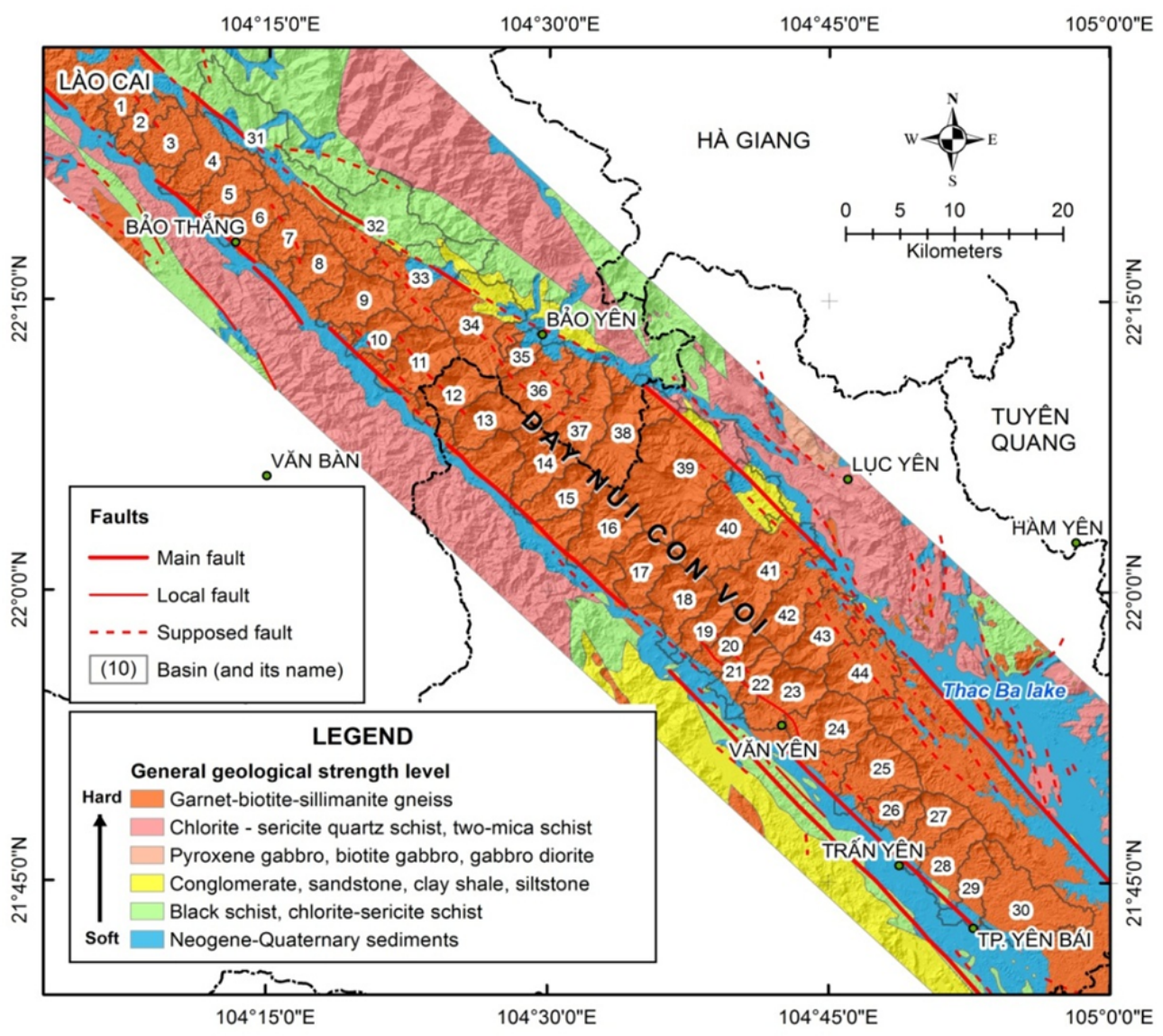

Figure 2. Geological strength level map in the Day Nui Co Voi and surrounding area

As for the Ailao Shan, the DNCV is a narrow high-grade metamorphic rocks and are mapped as Proterozoic (Phan et al., 1994; 2012). It is composed chiefly of garnetbiotite-sillimanite gneiss and garnet-biotite gneiss, and minor two-mica schists with garnet (Figure 2). The DNCV also includes amphibolite layers, migmatites, mylonite bands and small lenses of marble. This rock assemblage suggests that the DNCV was formed with severe deformation and deep metamorphism of sedimentary rocks (Tran et al., 1998; Phan et al., 1994; 2012). The rocks within the DNCV are strongly foliated. The foliation, which is marked by the preferred orientation of planar minerals (biotite and amphibole) and by flattened quartz or feldspar ribbons, commonly strikes parallel to the local trend of the gneiss core and dips steeply $\left(\sim 70^{\circ}\right)$ to the northeast. The lineation is deduced by elongated quartz and feldspar ribbons, long tails of feldspar porphyroblasts, stretched leucocratic veins and preferred orientations of sillimanite crystal shapes all locally plunge to the northwest in a range of 5-20 (Tran et al., 1998). A mylonite band about 200-500 $\mathrm{m}$ wide is well exposed in the center of the northeastern flank of the shear zone. Foliation and lineation within the mylonite band are parallel to those of the host gneisses. Numerous kinematic indicators suggest a left-lateral shear movement of this mylonite band (Phan et al., 1995; Tran et al., 1998). The foliation of gneisses is then cut by two sets of steep conjugate faults, $\mathrm{N} 10^{\circ} \mathrm{E}$ striking dextral and more numerous $\mathrm{N} 110^{\circ} \mathrm{E}$ 
Vietnam Journal of Earth Sciences, 38(2), 202-216

striking sinistral, indicating $\mathrm{N} 60^{\circ} \mathrm{E}$ shortening. It shows that a successive deformation with ENE shortening (Tran et al., 1998).

From Vietnam-China border, at Lao Cai, the Red River valley fault splays into two roughly parallel strands, the Chay River and Red River faults, which bound the DNCV to the north and south, respectively. Currently, both fault-strands appear to slip mostly rightlateral slip, with variable components of normal slip (Allen et at., 1984; Phan et al., 1994, 2004, 2012). Narrow straight 'grabens', which are traced along the Red River and Chay River faults, are filled with Late Miocene sediments containing abundant pebbles of gneisses and mylonites, being interpreted as a synorogenic formation resulting fromthe reversal of fault movements from left-lateral to right-lateral about $5 \mathrm{~m}$.y. ago (Leloup et al., 1994). On the SW and NE sides of the DNCV also exist some small faults run nearly parallel with the Red River and Chay River faults, respectively (Le et al., 2004).

\section{Data and methods}

To determine the hypsometric curve and its statistical moments for the study area, we used Digital Elevation Model (DEM) with $30 \mathrm{~m}$ resolution which is provided by the United States Geological Survey (USGS). The DEM is analyzed by ArcGIS software; it is useful tools to ensure accuracy, quick and less expensive in the calculation of morphology parameters. The calculation in this study is carried out automatically using the extension tools of ArcGIS 10.1 software (Pérez-Peña et al., 2009). Geological map of the study area was constructed using the digital Geological and Mineral Resources maps at the scale of 1:200,000 (The Department of Geology and Minerals of Vietnam). We used the active faults from the Phan et al. (2004, 2012), Ngo et al. (2006, 2011), and Le et al. (2004).

\subsection{Hypsometric curve and hypsometric integral}

The hypsometric curve describes the distribution of elevations across an area of land with different scales from one drainage basin to the entire planet. The curve is created by plotting the proportion of total basin height ( $\mathrm{h} / \mathrm{H}=$ relative height) against the proportion of total basin area $(\mathrm{a} / \mathrm{A}=$ relative area $)$ (Strahler, 1952; Keller and Pinter, 2002) (Figure 3). The shape of the hypsometric curve is related with the stage of geomorphic development of the basin. Convex hypsometric curves are typical of a youthful stage; S-shaped curves are related to a maturity stage, and concave curves are indicative of a peneplain stage (Strahler, 1957; Gardner et al., 1990; Delcaillau et al., 1998; Keller and Pinter., 2002; Pérez-Peña et al., 2009) (Figure 3).

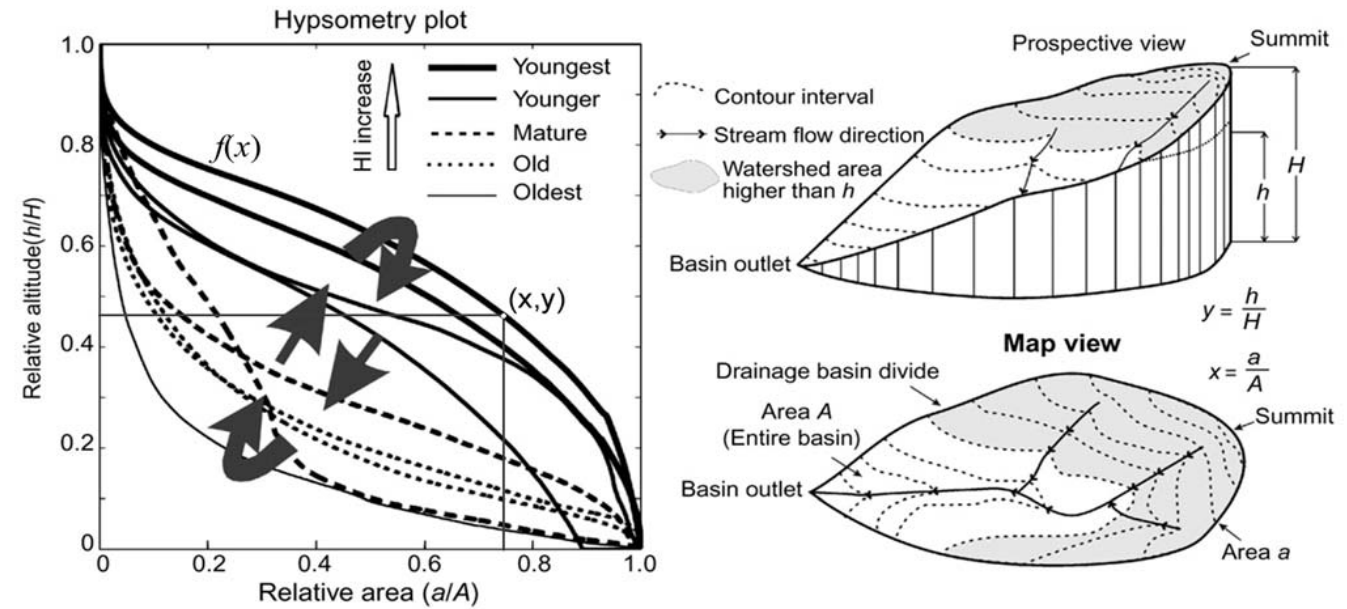

Figure 3. Basic hypsometric curves and its geomorphological development cycles (Modified after Strahler, 1952; Pérez-Peña et al., 2009; Mahmood and Gloaguen, 2012) 
N.V. Liem, et al./Vietnam Journal of Earth Sciences 38 (2016)

A simple way to characterize the shape of the hypsometric curve for a given drainage basin is to calculate its hypsometric integral (HI). The integral is defined as the area under the hypsometric curve and can be calculated (Keller and Pinter, 2002):

$$
\mathrm{HI}=\left(\mathrm{H}_{\text {mean }}-\mathrm{H}_{\min }\right) /\left(\mathrm{H}_{\max }-\mathrm{H}_{\min }\right)
$$

where $\mathrm{HI}$ is hypsometric integral, $\mathrm{H}_{\max }$ is maximum elevation, $\mathrm{H}_{\min }$ is minimum elevation, and $\mathrm{H}_{\text {mean }}$ is mean elevation.

The parameters in the formula (1) can be identified by analyzing the DEM with the GIS software. The HI index has been used, as well as the hypsometric curve, to infer the stage of development of a basin. The values of the HI always vary from 0 to 1 . Values near 1 indicate a state of youth and are typical of convex curve. However, in the mature stage of the basin, it has a lot of S-shape and concave shape but the HI values often similar. Meanwhile, to distinguish or assessment correlate between the basins, we often base on the statistical indices are given below.

\subsection{Statistical moments of the hypsometric curve}

In addition to analyzing hypsometric integral (HI) index, we also calculate and analyze other statistic moments of hypsometric curve (HC): skewness of the hypsometric curve (hypsometric skewness, SK), kurtosis of the hypsometric curve (hypsometric kurtosis, KUR), skewness of the hypsometric density function (density skewness, DSK), and kurtosis of the hypsometric density function (density skewness, DKUR).

Harlin (1978) developed a technique that treated the hypsometric curve as a cumulative probability distribu-tion and used its statistic moments to describe it quantitatively. It consists of the hypsometric curve by a continuous polynomial function with the form (Harlin, 1978) (Figure 3).

$$
f(x)=a_{0}+a_{1} x+a_{2} x^{2}+\ldots+a_{n} x^{n}
$$

and $\mathrm{HI}$ can be defined:

$$
\mathrm{HI}=\iint_{R} d x d y
$$

where $R$ is the region under the hypsometric curve, $x$ is relative area, and $y$ is relative height.

Skewness of the hypsometric curve is defined by:

$$
\mathrm{SK}=\mu_{3} /\left(\mu_{2}{ }^{1 / 2}\right)^{3}
$$

where $\mu_{3}$ and $\mu_{2}$ are the third-order and second-order moment about $\mathrm{x}$,

$$
\begin{aligned}
& \mu_{3}=\frac{1}{\mathrm{HI}} \iint\left(x-\mu_{1}\right)^{3} d x d y \\
& \mu_{2}=\frac{1}{\mathrm{HI}} \iint\left(x-\mu_{1}\right)^{2} d x d y
\end{aligned}
$$

where $\mu_{1}$ is the fist-order moment or $\mathrm{x}$ mean or $\mathrm{x}$ centroid,

$$
\mu_{1}=\iint_{R} x d y d x
$$

Kurtosis of the hypsometric curve is defined by:

$$
\mathrm{KUR}=\frac{\mu_{4}}{\left(\mu_{2} 1 / 2\right)^{4}}
$$

where $\mu_{4}$ is fourth-order moment about $\mathrm{x}$,

$$
\mu_{4}=\frac{1}{\mathrm{HI}} \iint\left(x-\mu_{1}\right)^{4} d x
$$

Density skewness (DSK) and density kurtosis (DKUR) are defined similarly except that now $y$ is the first derivative of the hypsometric curve, i.e., the density function of the hypsometric curve (replacing y with y'). These definitions are chosen so that they are consistent with Harlin's original work (Harlin, 1978).

In statistics, skewness and kurtosis describe the shape of a distribution relative to the normal distribution and are dimensionless. Skewness characterizes the degree of asymmetry of a distribution around its mean. A positive value of skewness $(\mathrm{SK}>0)$ signifies a distribution with an asymmetric tail extending out toward a more positive $\mathrm{x}$ (skewed to the right); a negative value $(\mathrm{SK}<0)$ signifies a distribution whose tail extends out toward a more negative $\mathrm{x}$ (skewed to the left); and the skew is zero $(\mathrm{SK}=0)$, when the variable distribution is symmetrical. Kurtosis measures the relative peakedness or flatness of a distribution, relative to a normal distribution. Larger kurtosis (KUR>3) indicates a "sharper" 
Vietnam Journal of Earth Sciences, 38(2), 202-216

peak than normal distribution (the same Luo, 2000 and Pérez-Peña et al., 2009, under the definition used in this paper, the kurtosis of a normal distribution is 3); smaller kurtosis indicates "flatter" peak than normal distribution.

These statistics are applied to the distribution function of the hypsometric curve order to explain the erosion and slope basins and has been tested by Harlin., (1978); Luo., (1998, 2000); Pérez-Peña et al., (2009). Accordingly, the hypsometric skewness represents the amount of headward erosion in the upper reach of a basin (Figure 4); density skewness indicates slope change; a large value of kurtosis signifies erosion on both upper and lower reaches of a basin, and density kurtosis delineates midbasin slope.
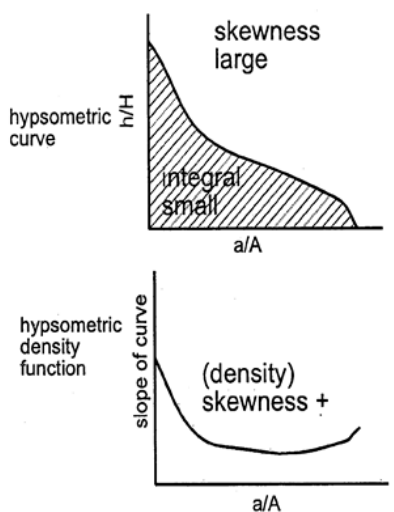

$\mathrm{a} / \mathrm{A}$

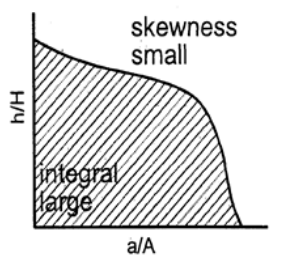

a/A

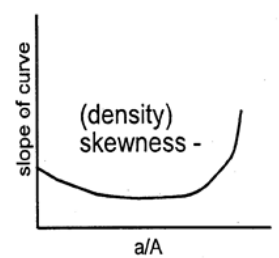

$\mathrm{a} / \mathrm{A}$
Figure 4. Schematic diagram showing the relationship between the shape of the hypsometric curve and its integral, skewness, and density skewness (Luo, 2000)

These statistical moments can be used to describe and characterize the shape of the hypsometric curve and, hence, to quantify changes in the morphology of the drainage basins. In many cases, these parameters are very useful for the hypsometric analysis, especially in basins with similar hypsometric integrals but different shapes (Pérez-Peña et al., 2009).

\section{Results}

In the DNCV area, the hypsometric curve analysis method and its statistical moments are used for assessment at 44 sub-basins of the
Red river and the Chay river. In which, 30 sub-basins are located in the Red River (from the basin 1 to 30 ) and 14 sub-basins are located in the Chay River (from the basin 31 to 44) (Figure 5). The results are showed on Table 1, Figures 5 and 6.

In the study area, the hypsometric curve can be grouped into 3 curves: "straightshape", "S- shape", and concave curves (Figs. $6 \mathrm{a}, 6 \mathrm{~b}$ and $6 \mathrm{c}, \mathrm{d}$, respectively) and no convex curve. Accordingly, concave curve has the largest proportion (26/44 basins), followed by the S-shape (10/44 basins) and final are straight-shape (8/44 basins). Consistent with them, the HI indices are also very small, the largest value is the basin No.13 $(\mathrm{HI}=0.37)$ and the smallest is the basin No.28 (HI = 0.128 ). In which, the basins with "straightshape" have the HI values are greater than 0.3 ; the "S-shape" have HI values are greater than 0.25 and the concave curves with largest HI value is 0.28 (Table 1 ).

The results shown in Table 1 show that the skew values are from 0.45 to 1.3 and these values do not change much in the basins with straight-shape of the hypsometric curve (the skew values range from 0.55 to 0.83 ) and the "S-shape" of the hypsometric curve $(0.45<$ SK $<0.64)$. In contrary, the skew values have considerable variability in the basins with concave shape of hypsometric curve (the skew values range from 0.46 to 1.3 ). In the basins with straight-shape and s-shape of hypsometric curve, the density skew values range from 0.33 to 0.96 , and the basins have concave curve, this values range from $\sim 0.78$ to 1.58 . The kurtosis values range from $\sim 2.0$ to 4.1 ; in there, the basins have the hypsometric curve with the "straight" and "S" shape, the kurtosis values are less than 3.0 (the kurtosis of a normal distribution is 3.0). The density kurtosis values range from 1.75 to 4.87 . As the skew values, the density kurtosis values are not change much in the hypsometric curve basins with the "straight" and " $\mathrm{S}$ " shape, and quite change in the concave shape basins. The variation values of the main statistical moments indices in the DNCV are showed on Figure 7. 
N.V. Liem, et al./Vietnam Journal of Earth Sciences 38 (2016)

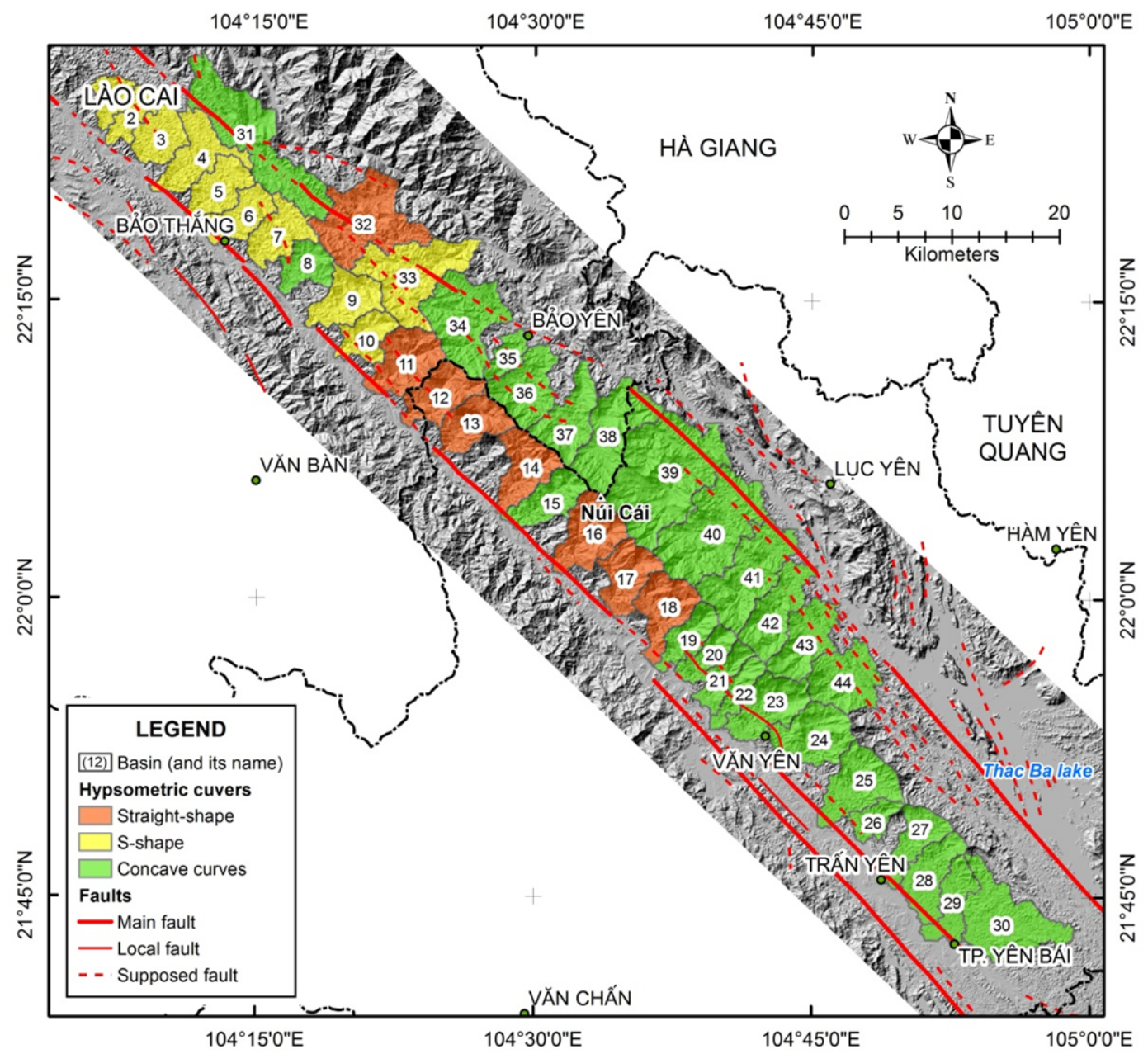

Figure 5. Schematic distribution of the hypsometric curve in the DNCV area

\section{Discussion}

The hypsometric curve and its statistical moments influenced by active tectonics, are also affected by geological and regional climatic characteristics (Moglen and Bras, 1995; Willgoose and Hancock, 1998; Huang and Niemann, 2006; Pedrera et al., 2009). Because the study area is located almost in the center of the DNCV with a narrow range, so the climate is basically not much different. According to the geological map $(1: 200,000)$ of the Department of Geology and Minerals of Vietnam, the DNCV area has identical geol- ogy and is composed chiefly of high-grade metamorphic rocks (Figure 2). So, anomalies (if any) of geomorphic indices in this area are mainly a reflection of the recent tectonic activity.

Regarding to the difference of the number basins in the northeast side (14/44) and the southwest side (30/44) of the DNCV area, because in the southeastern part of this area has the Thac Ba hydropower dam, so the basins should flow directly into the lake having been changed base erosion level by the volume of water. Therefore, we did not use these basins in the calculations. On the other hand, due to 
Vietnam Journal of Earth Sciences, 38(2), 202-216

relief features of the DNCV with slopes in the southwestern side (in the Red River basin) is greater than the northeastern side (in the Chay River basin). Therefore, area of the basins in the southwestern side usually smaller than the northeastern side and opposite side, the number of basins in the northeastern side is
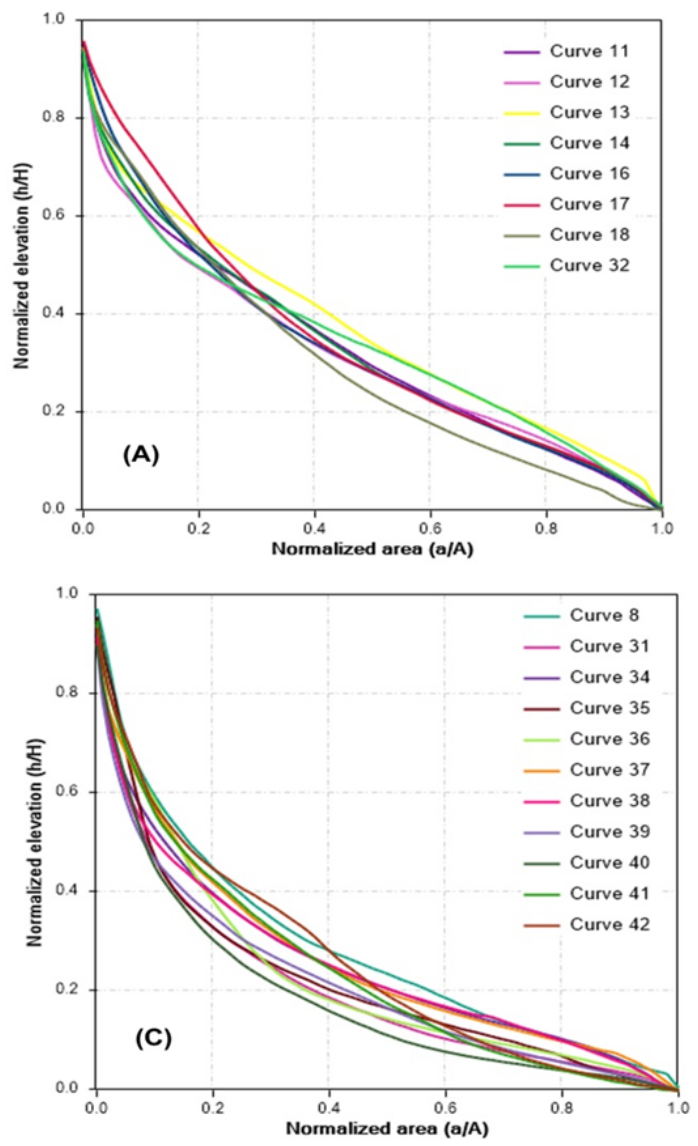

less than in the southwestern side. The steeper and higher of the southwestern side than the northeastern side reflected lift active of the DNCV in the southwestern side is higher than the northeastern side. This will be clarified by analyze the hypsometric curve and its statistical moments as below.
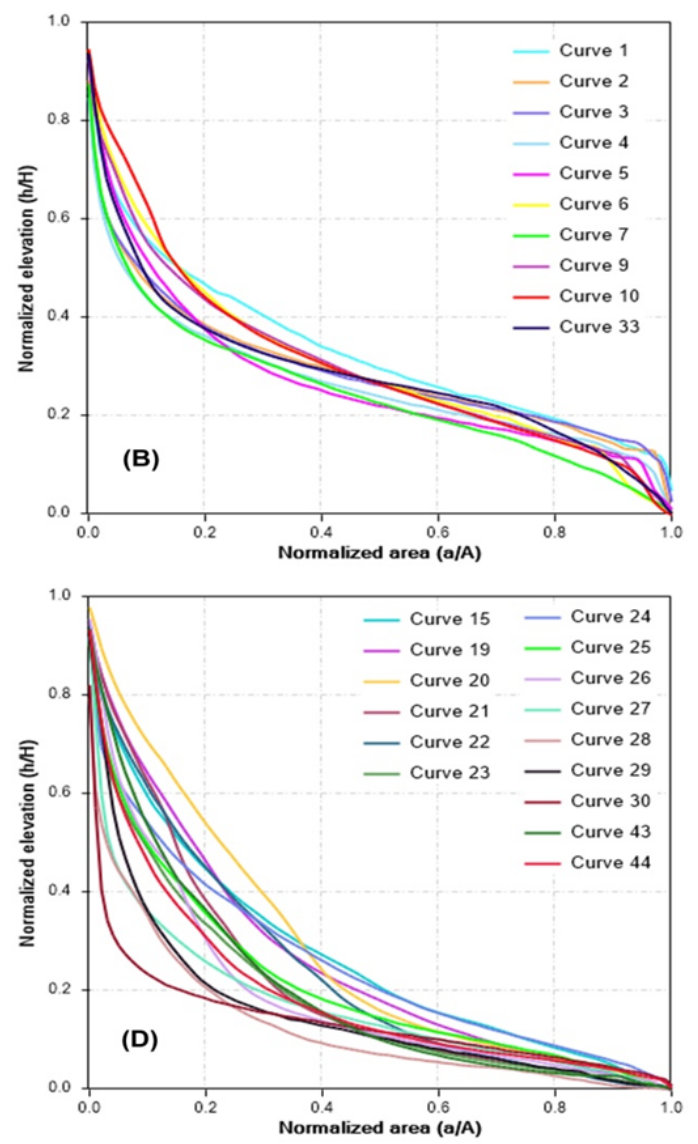

Figure 6. Hypsometric curves of the sub-basins in the DNCV area; (A) - "Straight-shape" group; (B)- "S-shape" group; (C) and (D)- concave curves

As the results presented above, in the study area, the hypsometric curve has revealed 3 curves such as "straight- shape", "S- shape", and concave curves, but no convex curve. In there, the hypsometric curve is almost concave curve (26/44 basins) and fit it, the HI values mainly small; maximum is 0.37 (Figure 5 and Table 1). Accordingly, the basin in this study area is mainly in the oldest stage, meaning that the basin has reached the equilibrium in the longitudinal profiles of the river (or stream). In these basins, the dominant geomorphological processes usually are lateral erosion, vertical erosion (if any) also occurs in the upstream area. Another way, the active tectonics (uplift-lower) in these basins is basically weak. However, there still exists the hypsometric curve as "straight- 
N.V. Liem, et al./Vietnam Journal of Earth Sciences 38 (2016)

shape" and "S-shape" are distributed in some parts of the study area and focused mainly in the northern part to the center of the southwestern side of the DNCV. Whereas, in the northeastern side of the DNCV, the hypsometric curve mainly is concave curve (Figure 5 and 6a,b). Tectonic activity in the study area is not fully uniform. Accordingly, uplift active in the southwestern side (Red River basin) basically is greater than that in the northeastern side (Chay River basin). In which, some of the northern segment uplifted is greater than southern segment (Figure 5). This result is consistent with Le et al. (2001, 2004). In the northeastern side, where the Chay River fault cuts across at the foot of the slope, almost of basins with hypsometric curve are concave curve, except the basin 32 and 33. This is consistent with previous studies that Chay River fault is right-lateral slip (Nguyen, 2002; Phan et al., 2004, 2012; Ngo et al., 2006, 2011).

Table 1. The statistical moments of the hypsometric curve in the DNCV area (HI - Hypsometric integral, SK - Skew; KUR - Kurtosis, DSK - Density skew and DKUR - Density kurtosis

\begin{tabular}{|c|c|c|c|c|c|c|c|c|c|c|c|}
\hline No & $\mathrm{HI}$ & SK & KUR & DSK & DKUR & No & $\mathrm{HI}$ & SK & KUR & DSK & DKUR \\
\hline 1 & 0.335 & 0.526 & 2.141 & 0.666 & 2.002 & 23 & 0.188 & 1.174 & 3.626 & 1.402 & 4.109 \\
\hline 2 & 0.294 & 0.451 & 2.016 & 0.614 & 1.758 & 24 & 0.255 & 0.816 & 2.726 & 0.839 & 2.485 \\
\hline 3 & 0.294 & 0.452 & 2.003 & 0.736 & 1.956 & 25 & 0.214 & 0.953 & 2.900 & 1.189 & 3.158 \\
\hline 4 & 0.269 & 0.487 & 2.055 & 0.658 & 1.829 & 26 & 0.190 & 1.169 & 3.341 & 1.550 & 4.203 \\
\hline 5 & 0.272 & 0.609 & 2.164 & 0.964 & 2.370 & 27 & 0.169 & 0.848 & 2.560 & 1.070 & 2.653 \\
\hline 6 & 0.309 & 0.595 & 2.221 & 0.612 & 1.804 & 28 & 0.128 & 1.183 & 3.328 & 1.499 & 3.987 \\
\hline 7 & 0.250 & 0.579 & 2.200 & 0.555 & 1.724 & 29 & 0.156 & 1.019 & 2.766 & 1.346 & 3.282 \\
\hline 8 & 0.284 & 0.788 & 2.607 & 0.867 & 2.410 & 30 & 0.137 & 0.626 & 2.138 & 0.904 & 2.147 \\
\hline 9 & 0.305 & 0.598 & 2.236 & 0.662 & 1.916 & 31 & 0.205 & 0.983 & 2.974 & 1.218 & 3.249 \\
\hline 10 & 0.311 & 0.643 & 2.285 & 0.752 & 2.039 & 32 & 0.344 & 0.550 & 2.232 & 0.327 & 1.591 \\
\hline 11 & 0.329 & 0.667 & 2.482 & 0.444 & 1.864 & 33 & 0.290 & 0.463 & 1.999 & 0.495 & 1.525 \\
\hline 12 & 0.320 & 0.642 & 2.386 & 0.517 & 1.848 & 34 & 0.254 & 0.752 & 2.498 & 0.841 & 2.277 \\
\hline 13 & 0.370 & 0.605 & 2.375 & 0.339 & 1.759 & 35 & 0.220 & 0.860 & 2.570 & 1.063 & 2.644 \\
\hline 14 & 0.333 & 0.706 & 2.562 & 0.525 & 2.010 & 36 & 0.227 & 1.033 & 3.112 & 1.324 & 3.638 \\
\hline 15 & 0.270 & 0.848 & 2.792 & 0.873 & 2.539 & 37 & 0.261 & 0.825 & 2.673 & 0.970 & 2.661 \\
\hline 16 & 0.329 & 0.717 & 2.523 & 0.649 & 2.070 & 38 & 0.252 & 0.727 & 2.456 & 0.780 & 2.155 \\
\hline 17 & 0.347 & 0.773 & 2.667 & 0.714 & 2.292 & 39 & 0.214 & 0.885 & 2.812 & 0.976 & 2.689 \\
\hline 18 & 0.304 & 0.833 & 2.877 & 0.688 & 2.366 & 40 & 0.185 & 1.137 & 3.381 & 1.415 & 3.916 \\
\hline 19 & 0.259 & 0.994 & 3.176 & 1.082 & 3.150 & 41 & 0.240 & 0.933 & 3.032 & 0.970 & 2.916 \\
\hline 20 & 0.282 & 1.126 & 3.756 & 1.003 & 3.402 & 42 & 0.257 & 0.889 & 3.000 & 0.820 & 2.665 \\
\hline 21 & 0.213 & 1.302 & 4.040 & 1.575 & 4.805 & 43 & 0.199 & 1.306 & 4.100 & 1.563 & 4.875 \\
\hline 22 & 0.239 & 1.106 & 3.679 & 1.106 & 3.567 & 44 & 0.191 & 1.064 & 3.101 & 1.453 & 3.925 \\
\hline
\end{tabular}

According to Al Hamdouni et al. (2008), the hypsometric curve often has convex curve when $\mathrm{HI}$ index greater than 0.5 ; intermediate form between the concave and convex shape (S-shape) or "straight-shape" when the HI value in the range of 0.4 to 0.5 and the HIvalue less than 0.4 , the hypsometric curve has a concave shape. In the study area, as the Table 1, Figure 5 and Figures $6 a, b$, the HI values of the hypsometric curve with straight- shape and S-shape are less than 0.4 and smallest is 0.25 . Thus, when using and analyzing the $\mathrm{HI}$ index in different areas, need to combine with its hypsometric curve. Because in many cases, the basins with similar hypsometric integrals but different shapes (Pérez-Peña et al., 2009). In that cases, these other statistical moments are necessary to consider for the hypsometric analysis (Figure 7a, b). 
Vietnam Journal of Earth Sciences, 38(2), 202-216
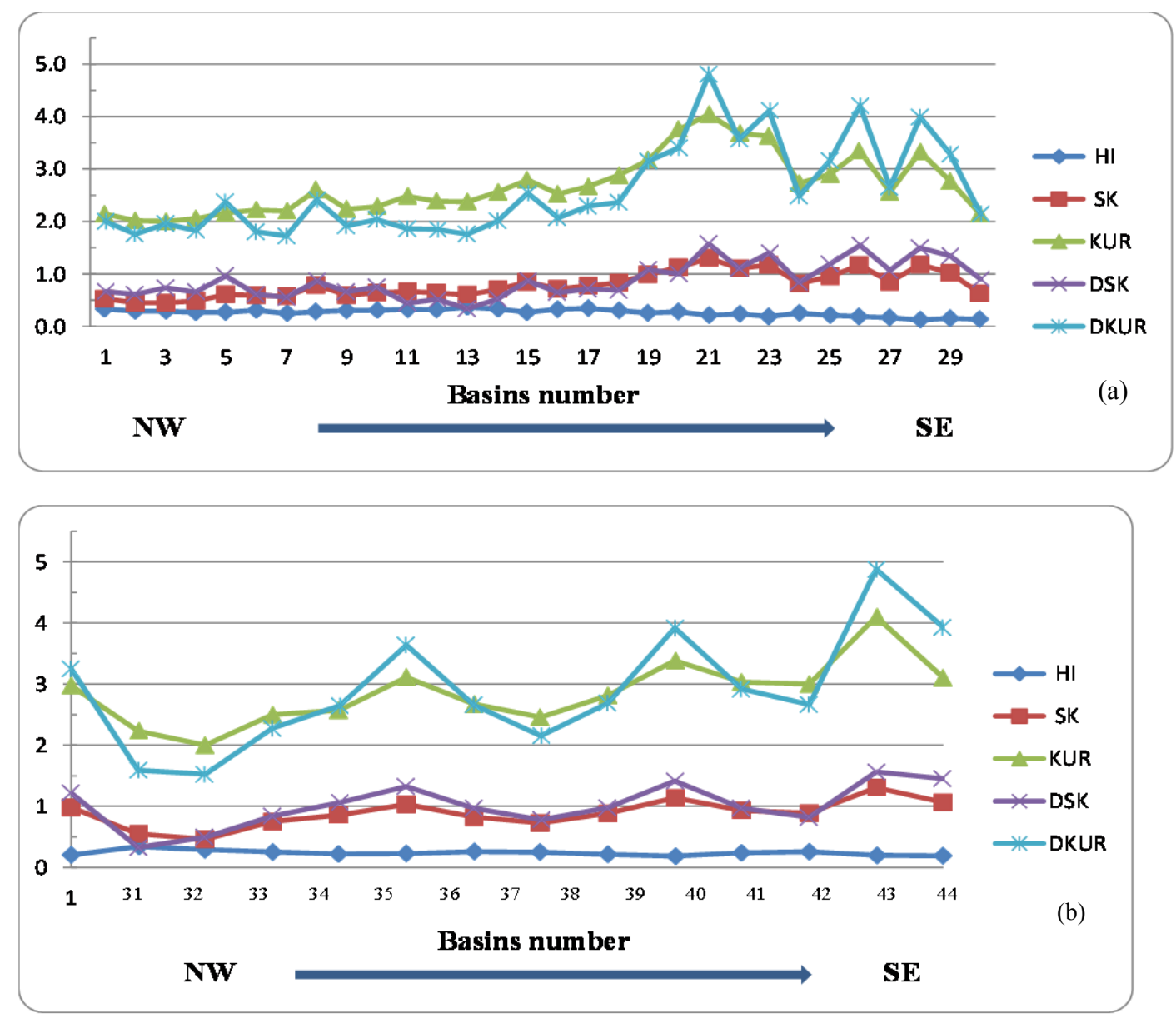

Figure 7. a) The variation of the statistical moments of the hypsometric curve (the basins in the southwestern side of the DNCV); b) The variation of the statistical moments of the hypsometric curve (the basins in the northeastern side of the DNCV)

In the study area, according to the results in Table 1, Figure $7(\mathrm{a}, \mathrm{b})$ and in the direction from northwest to southeast, unless the HI index (downward trend), basically, other statistical moments of the hypsometric curve are likely to increase in both sub-basin systems of the Red River and Chay River. As the results of skew, the values range from 0.45 to 1.3 $(\mathrm{SK}>0)$, this mean the basins in the study with the geomorphological processes almost are represent the amount of headward erosion in the upper reach of the basin (Harlin, 1978;
Luo, 2000; Pérez-Peña et al., 2009). This trend is basically increased in the direction from northwest to southeast to the basin of the study area. Consistent with SK index, the DSK index also reflects a larger slope in the upper reach of the basin and also showed upward trend from northwest basins to the southeast basins. In addition, a larger value of kurtosis (almost is the concave shape in the southern of the DNCV in both the northeast and southwest sides; Table 1 and Figure 7) signifies erosion on both upper and lower 
N.V. Liem, et al./Vietnam Journal of Earth Sciences 38 (2016)

reaches of a basin (Harlin, 1978; Luo, 2000). These results also showed, in the basins which have large KUR values then so are DKUR values (Table 1 and Figure 7). This mean that, this basin also has large slope in the middle part of the basin (Harlin, 1978; Luo, 2000; Pérez-Peña et al., 2009). What makes this area contain these features (erosion process in the both of the upstream and downstream area, and addition large slope in the middle part)? According to Le $(2001,2004)$ and Ngo (2011), the regional topography has stepped clearly. This step by the heterogeneously raising activities and the active fault branches (of the Red River and the Song Chay Faults) on both the northeast and southwest sides of the DNCV area (Le, 2001, 2004; Ngo, 2011).

According to Pérez-Peña et al. (2009), the value increases of the KUR and DKUR indexes (when the same hypsometric curve and hypsometric integral index) often show upward trend of recent tectonic activity. However, in the study area, the higher anomalies of the KUR and DKUR indexes still lie in the basins with the hypsometric curve showing concave shape (Table 1, Figure 5 - Figure 7). Thus, if only individual basins with curve concave shape are considered, basins with larger KUR and DKUR values will show stronger tectonic activity. If all basins of the study area are considered, the higher anomalies KUR and DKUR indexes at the basins with concave curve shape possibly suggest the following remarks: According to basic hypsometric curve model and geomorphological development cycles shown by the changes of the hypsometric curves (Figure 3), the hypsometric curves with concave curve shape are the oldest stage of geomorphological cycles, and it is the final stage of the cycle to stabilize the tectonic cycle to pass on to a new tectonic activity cycle. This means, the tectonic active in the study area possibly is the last period of stabilization tectonic cycle and the beginning of a new tectonic activity cycle. If so, the above assumption is appropriated in anticipation of Allen (1984) to repeat the cycle of large earthquakes along the Red River Fault Zone is about 1800 years, while in the region of Yunnan, China had strong earthquake occurred 8.1 to 8.3 on the Richter scale and occurred approximately 1000 to 2000 years ago.

In summary, the hypsometric curves in the study area are mainly concave shapes; some curves are intermediate form between the concave and convex shape (in "straight" and "S" shape). HI index is basically small and tends to decrease to the southeast. The skew and kurtosis and their density function are basically large and increasing trend to the southeast. An overview, the recent tectonic activity (uplift - lower) in the study area is generally weak. In which, the southwestern side is being lifted higher than the north-eastern side. The northern part is being lifted larger than the southern part. In the region and surrounding area, the strong uplift activities and increased gradually in the Pliocene-Quaternary (modeled after Le et al., 2004) could have stopped at certain time in the past. The current geomorphic processes are mainly headward erosion in the upstream. These results will be clarified in the next study when there is a combination of many different geomorphic indices.

\section{Conclusions}

The hypsometric curves and its statistical moments are useful tools to assess the geomorphological processes and recent tectonic activity of the region as well as the comparison between different zones.

The Day Nui Con Voi area has revealed 3 curves such as "straight- shape", "S- shape", and concave curves. The concave curve is the most common widely distributed in the northeast side and the southern part of the southwestern side of the DNCV area. The hypsometric integral (HI) values are rather small, the largest value is 0.37 whereas the smallest one is 0.128 . Other statistical mo- 
Vietnam Journal of Earth Sciences, 38(2), 202-216

ments of the hypsometric curve i.e. skew (SK), kurtosis (KUR), and the density function (density skew - DSK and density kurtosis-DKUR) have great values and increase in the south direction of the area study.

The recent active tectonic activities (upliftlower) of the study area are generally weak. However, they are also not completely homogeneous and can be distinguished by different levels. The southwestern side is being lifted higher than the north-eastern side. The northern part is being lifted larger than the southern part. In the region, the uplift activities were increased gradually in the Pliocene-Quaternary and could have stopped at certain time in the past. The current geomorphic processes are mainly headward erosion in the upstream.

\section{Acknowledgments}

The study is a part of the research project VAST 05.02/14-15 funded by the Vietnam Academy of Science and Technology (VAST). Authors would like to thank.

\section{References}

Allen, C.R., Gillepie, A.R., Han, Y., Sieh, K.E., Zhu, C., 1984. Red River and associated faults, Yunnan province, China: Quaternary geology, slip rates, and seismic hazard, Geological Society of America Bulletin, 686-700, 21 fig.

Azor, A., Keller, E.A., Yeats, R.S., 2002. Geomorphic indicators of active fold growth: South Mountain-Oak Ridge anticline, Ventura basin, southern California. Geological Society of America Bulletin 114, 745-753.

Chen, Y.C., Sung, Q., Cheng, K.Y., 2003. Along-strike variations of morphotectonic features in the Western Foothills of Taiwan: tectonic implications based on stream gradient and hypsometric analysis. Geomorphology 56, 109-137.

Delcaillau, B., Deffontaines, B., Floissac, L., Angelier, J., Deramond, J., Souquet, P., Chu, H.T., Lee, J.F., 1998. Morphotectonic evidence from lateral propagation of an active frontal fold; Pakuashan anticline, foothills of Taiwan. Geomorphology 24, 263-290.

Delcaillau, B., Laville, E., Amhrar, M., Namous, M., Dugué, O., Pedoja, K., 2010. Quaternary evolution of the
Marrakech High Atlas and morphotectonic evidence of activity along the Tizi N'Test Fault, Morocco. Geomorphology 118, 262-279.

El Hamdouni, R., Irigaray, C., Fernández, T., Chacón, J., Keller, E.A., 2008. Assessment of relative active tectonics, southwest border of the Sierra Nevada (southern Spain). Geomorphology 96, 150-173.

Font, M., Amorese, D., Lagarde, J.L., 2010. DEM and GIS analysis of the stream gradient index to evaluate effects of tectonics: the Normandy intraplate area (NW France). Geomorphology 119, 172-180.

Gardner, T.W., Sasowsky, K.C., Day, R.L., 1990. Automated extraction of geomorphometric properties from digital elevation models. Zeischrift für Geomorphologie Supplemental Band 80, 57-68.

Harlin, J.M., 1978. Statistical moments of the hypsometric curve and its density function. Mathematical Geology 10, 59-72.

Howard, A.D., 1990. Role of hypsometry and planform in basin hydrologic response. Hydrological Processes 4, 373-385.

Huang, X.J., Niemann, J.D., 2006. Modelling the potential impacts of groundwater hydrology on long-term drainage basin evolution. Earth Surface Processes and Landforms 31, 1802-1823.

Joshi, P.N,. Maurya, D.M., Chamyal, L.S., 2013. Morphotectonic segmentation and spatial variability of neotectonic activity along the Narmada-Son Fault, Western India: Remote sensing and GIS analysis. Geomorphology 180-181 (2013) 292-306.

Keller, E.A., Pinter, N., 2002. Active Tectonics. Earthquakes, Uplift and Landscape. Prentice Hall, New Jersey, 362.

Le Duc An, 2003. About the exhumation of metamorphic rocks of Con Voi range. Vietnam Journal of Earth Sciences,No.1, 93-95 (In Vietnamese with English abstract).

Le Duc An, Dao Dinh Bac, Uong Dinh Khanh, Vo Thinh, Tran Hang Nga, Ngo Tuan Anh, Nguyen Thi Le Ha, 2004. Geomorphology of Red River Fault Zone and natural hazard.P 459-532. Science and Technics Publishing House, Hanoi (In Vietnamese with English abstract).

Le Duc An, Lai, Huy Anh, Vo Thinh, Ngo Tuan Anh, Do Minh Tuan, Tran Hang Nga, 2001. Steps of relief of Convoi Mountain characteristics. Vietnam Journal of Earth Sciences, 23(2), 97-104. (In Vietnamese with English abstract).

Leloup, P.H., Arnaud, N., Lacassin, R., Kienast, J.R., Harrison, T.M., Trinh, P.T., Replumaz, A., Tapponnier, P., 2001. 


\section{N.V. Liem, et al./Vietnam Journal of Earth Sciences 38 (2016)}

New constraints on the structure, thermochronology, and timing of the Ailao Shan-Red River shear zone, SE Asia, Journal of Geophysical Research, B, v. 106, 6683-6732.

Leloup, P.H., Chen Wenji, Harrison, T.M., Tapponnier, P., 1994. Timing of shear sense inversion along the Red River fault zone. Int. Workshop on Seismotectonics and Seismic Hazard in South East Asia, Hanoi.

Leloup, P.H., Lacasin, Tapponnier, P., Scharer, U., Dalai, Z., Xaohan, L., Zhangshan, Shaocheng, J., Trinh, P.T., 1995. The Ailao Shan - Red Rive shear zone (Yunnan, China), Tertiary transform boundary of Indochina. Tectonophysics, v. 251, pp. 3-84.

Leloup, P.H., Lacassin, R., Tapponnier, P., Harrison, T.M., 2001. Comment on "Onset timing of left-lateral movement along the Ailao Shan \pm Red River Shear Zone: $40 \mathrm{Ar} / 39 \mathrm{Ar}$ dating constraint from the Nam Dinh Area, northeastern Vietnam" by Wang et al., 2000. Journal of Asian Earth Sciences 18, 281-292. Journal of Asian Earth Sciences 20, 95-99.

Lifton, N. A., Chase, C.G., 1992. Tectonic, climatic and lithologic influences on landscape fractal dimension and hypsometry: implications for landscape evolution in the San Gabriel Mountains, California. Geomorphology 5, 77-114.

Luo, W., 1998. Hypsometric analysis with a geographic information system. Computers \& Geosciences, Vol. 245, No. 8, 815-821.

Luo, W., 2000. Quantifying groundwater- sapping landforms with a hypsometric technique. Journal of Geophysical Research, Vol. 105, No. El, Pages 1685-1694, January 25.

Mahmood, S. A., and Gloaguen, R., 2012. Appraisal of active tectonics in Hindu Kush: Insights from DEM derived geomorphic indices and drainage analysis. Geoscience Frontiers 3(4), 407-428.

Moglen, G.E., Bras, R.L., 1995. The effect of spatial heterogeneities on geomorphic expression in a model of basin evolution. Water Resources Research 31, 2613-2623.

Ngo Van Liem, 2011. Characteristics of landform evolution in relation to recent geodynamics along the Red River Fault Zone, Doctorate thesis, Institute of Geological Sciences, Hanoi (In Vietnamese with English abstract).

Ngo Van Liem, Phan Trong Trinh, Hoang Quang Vinh, 2006. The active faults and the maximum earthquakes of the Red River Fault zone in Lao Cai-Yen Bai area, Vietnam Journal of Earth Sciences, Vol. 28, (2), 110-120 (In Vietnamese with English abstract).

Ngo Van Liem, Phan Trong Trinh, Nguyen Van Huong, Nguyen Cong Quan, Tran Van Phong, Nguyen Phuc Dat, 2016. Analyze the correlation between the geomorphic indices and recent tectonic active of the Lo River fault zone in southwest of Tam Dao range. Vietnam Journal of Earth Sciences. Vol. 38, No. 1, 1-13 (In Vietnamese with English abstract).

Nguyen Quoc Cuong., Zuchiewicz, W., Tokarski. A. K., 1999. Morphotectonic evidence for right-lateral normal slip in the Red River Fault Zone: insights from the study on Tam Dao fault scarp (Viet Nam), J. Geology, Seri B, 13-14, 57-59.

Nguyen Xuan Nam, 2015. Quaternary Geology characteristics, present-day tectonic geomorphology of the Da river valley from HoaBinh to Viet Tri and correlation with geological hazards. Doctorate Thesis. Hanoi University of Mining and Geology (In Vietnamese with English abstract).

Ohmori, H., 1993. Changes in the hypsometric curve through mountain building resulting from concurrent tectonics and denudation. Geomorphology 8, 263-277.

Pedrera, A., Pérez-Peña, J.V., Galindo-Zaldívar, J., Azañón, J.M., Azor, A., 2009. Testing the sensitivity of geomorphic indices in areas of low-rate active folding (eastern Betic Cordillera, Spain). Geomorphology 105, 218-231.

Pérez-Peña, J.V., Azañón, J.M., Azor, A., 2009. CalHypso: An ArcGIS extension to calculate hypsometric curves and their statistical moments. Applications to drainage basin analysis in SE Spain. Computers \& Geosciences 35, 1214-1223.

Phan Trong Trinh, Hoang Quang Vinh, Leloup Philippe Hervé, Giuliani, G., Vincent Garnier., Tapponnier, P., 2004. Cenozoic deformation, thermodynamic evolution, slip mechanism of Red River shear zone and ruby formation. Science and Technics Publishing House, Hanoi. P5-72 (In Vietnamese with English abstract).

Phan Trong Trinh, Ngo Van Liem, Nguyen Van Huong, Hoang Quang Vinh, Bui Van Thom, Bui Thi Thao, Mai Thanh Tan, Nguyen Hoang, 2012. Late Quaternary tectonics and seismotectonics along the Red River fault zone, North Vietnam. Earth-Science Reviews 114, 224-235.

Phan Van Quynh, Vo Nang Lac, and Tran Ngoc Nam, 1995. Some features of late Paleozoic-Cenozoic deformation tectonics on the territory of Vietnam and neighboring areas. In: Geology, Mineral Resources and Petroleum of Vietnam. 
Vietnam Journal of Earth Sciences, 38(2), 202-216

Geological Survey of Vietnam, Hanoi, 171-183 (in Vietnamese with an English abstract).

Phung Thi Thu Hang, 2011. Study and comparison recent active tectonics between the Red River and the Dien Bien Lai Chau Fault Zones base on geomorphic indices. Master thesis. VNU University of Science, Hanoi.

Shahzad, F., and Gloaguen, R., 2011. TecDEM: AMATLAB based tool box for tectonic geomorphology, Part 1: Drainage network preprocessing and stream profile analysis. Computers \& Geosciences 37, 250-260.

Strahler, A.N., 1952. Hypsometric (area-altitude) analysis of erosional topography. Geological Society of America Bulletin 63, 1117-1142.

Strahler, A.N., 1957. Quantitative analysis of watershed geomorphology. Transactions of the American Geophysical Union 38, 913-920.

Tran Dinh To, 2002. The characterize of Neotectonics of Red River-Chay River Fault Zone. Doctorate Thesis, Institute of Geological Sciences, Hanoi, (In Vietnamese with English abstract).

Tran Dinh To, Duong Chi Cong, Vy Quoc Hai, Matthias Becker, Marina Neuman, 2003. Activity of Red River fault zone at Tam Dao-Ba Vi derived from GPS data (19941996-1998-2000). Vietnam Journal of Earth Sciences, 25(4)PC, 511-515 (In Vietnamese with English abstract).

Tran Dinh To, Nguyen Trong Yem, 2001.Amplitude and rate of slip of the Red River Zone in late Cenozoic. Vietnam Journal of Earth Sciences, 23(4), 334-353. (In Vietnamese with English abstract).

Tran Ngoc Nam, 1999. Red River Fault zone - focus of the scientific debate. Part II: P-T-t paths and post-metamorphic exhumation, Vietnam Journal of Earth Sciences, No.3, 161-167 (In Vietnamese with English abstract).
Tran Ngoc Nam, 2002. Exhumation mechanisms of the Day Nui Con Voi.Vietnam Journal of Earth Sciences, No.3, 286-288 (In Vietnamese with English abstract).

Tran Ngoc Nam, Mitsuhiro Toriumi, TetsumaruItaya, 1998. P-T-t paths and post-metamorphic exhumation of the Day Nui Con Voi shear zone in Vietnam. Tectonophysics 290, 299-318.

Tran Ngoc Nam., Toriumi, M., Sano, Y., Terada, K., Ta, T.T.,, 2003. 2.9, 2.36, and $1.96 \mathrm{Ga}$ zircons in orthogneiss south of the Red River shear zone in Viet Nam: evidence from SHRIMP U-Pb dating and tectonothermal implications. Journal of Asian Earth Sciences 21, 743-753.

Trinh Thi Thuy, 2014. Assessment of modern tectonic activity of the Son La fault zones on the basis of tectonic geomorphology. Master thesis. The University of Science Vietnam National University, Hanoi (In Vietnamese with English abstract).

Wang, P.L., Lo, C.H., Chung, S.L., Lee T.Y., Lan, C.Y., Thang, T.V., 2000. Onset timing of left-lateral movement along the Ailao Shan \pm Red River Shear Zone: 40Ar/39Ar dating constraint from the Nam Dinh Area, northeastern Vietnam. Journal of Asian Earth Sciences. Volume 18, Issue 3, 1 June 2000, 281-292.

Willgoose, G., 1994. A physical explanation for an observed area-slope-elevation relationship for catchments with declining relief. Water Resources Research 30, 151-159.

Willgoose, G., Hancock, G., 1998. Revisiting the hypsometric curve as an indicator of form and process in transportlimited catchment. Earth Surface Processes and Landforms $23,611-623$.

Zuchiewicz, W., Nguyen Quoc Cuong, Jerzy Zasadni, Nguyen Trong Yem, 2013. Late Cenozoic tectonics of the Red River Fault Zone, Vietnam, in the light of geomorphic studies. Journal of Geodynamics 69, 11-30. 